\title{
GOING, GOING, GONE. \\ EXIT FORMS AND THE INNOVATIVE CAPABILITIES OF FIRMS
}

\author{
Elena Cefis \\ University of Bergamo and Utrecht School of Economics, \\ Utrecht University, Janskerkhof 12, 3512 BL Utrecht, The Netherlands. \\ Tel +31.30.2539800; ecefis@rsm.nl

\section{Orietta Marsili} \\ Rotterdam School of Management, Erasmus University \\ Burg. Oudlaan 50, 3062 PA Rotterdam, The Netherlands. \\ Tel +31.10.4089508; omarsili@rsm.nl (corresponding author)
}

\section{November 2011}

\begin{abstract}
Although innovation is essential to build a competitive advantage and survive in the long run, some firms choose to exit, through mergers and acquisitions (M\&As), or radically change their business portfolio and identity. This paper examines how innovative capabilities influence the decision of a firm to exit, among business closure, M\&A, and radical restructuring. Using an analysis of a large and rich panel of Dutch manufacturing firms, we find that product and process innovation are equally important to lower the probability to close down activities, and this effect is stronger when product and process innovations are pursed in combination. We also find that process innovation reduces the probability of exit by radical restructuring, while product innovation, when not supported by process innovation, especially increases the probability of exit by M\&As. Our findings suggest that exit strategies are intimately bound to the nature and synergies of innovative efforts.
\end{abstract}

Keywords: Firm exit; Merger \& Acquisition (M\&A); Restructuring; Product and process innovation; Competing Risks Model

JEL codes:L11; L25; D21; O32 


\section{Introduction}

Staying in the market is a basic requisite for firm success. Traditionally, industrial economic studies have used the likelihood of survival (as opposed to exit) as an indicator of firm performance (Audretsch 1995, Caves 1998, Klepper 2002). Management studies, on the other hand, highlight firm exit as part of an overall strategy (Graebner and Eisenhardt 2004, Villalonga and McGahan 2005). As well as closing down activity or declaring bankruptcy, both signs of failure, a firm can choose to exit the market by merging with or selling out to another company. In these cases, exit does not equate with failure (Freeman et al. 1983, Headd 2003). In other circumstances firms engage in a process of restructuring that radically transform their identity and structure (Hoskisson and Turk 1990). Because firm exit can take different forms, exit behavior can be shaped by different factors (Schary 1991). The decision over whether to close down a business or to sell out to another company is influenced by firm specific characteristics, such as mode of entry, age and size (Mitchell 1994), by industry-specific factors, such as industry growth potential, and by the macro-economic conditions (Buehler et al. 2006).

According to Schumpeter (1934), innovation driven competition is what ultimately leads to the emergence in the market of winners and losers. Innovation explains 'especially in a competitive economy ... the process by which individuals and families rise and fall economically and socially and which is peculiar to this form of organization' (Schumpeter 1934, p. 67). Several studies have examined the effects of the innovative activities of the firm on its probability to survive (Hall 1987, Bruderl et al. 1992, Banbury and Mitchell 1995, Doms et al. 1995, Christensen et al. 1998, Colombo and Delmastro 2001, Esteve-Perez et al. 2004, Cefis and Marsili 2005, 2006, Bayus and Agarwal 2007, Ortega-Argiles and Moreno 2007, Buddelmeyer, Jensen and Webster 2010). In general innovative firms are found to be more viable, although some evidence suggests that investments in radical innovation can increase (rather than decrease) the probability to exit (Buddelmeyer, Jensen 
and Webster 2010). ${ }^{1}$ However, most of these studies measure the length of survival until the discontinuance of the firm, independent of whether this event consists in the disbanding of the firm or a M\&A, often because the data available do not allow distinctions to be made among different modes of exit (Agarwal and Audretsch 2001). Some studies concentrate on the effects of innovative activities on one specific form of exit, such as the closure of the firm (Banbury and Mitchell 1995) or the occurrence of a M\&A (Lehto and Lehtoranta 2004). Recent studies have started to explore the relationship between innovation and exit, distinguishing the liquidation of the business from a possible acquisition, with a focus on high-tech and new firms in specific industry settings (Fontana and Nesta 2009, Cockburn and Wagner 2010, Cefis and Marsili 2011). While these studies indicate that innovation can influence survival and exit, we need to know more about how the configuration of innovative capabilities of firms shape the overall choice of exit paths.

In this paper, we examine three different forms of exit: (a) exit by closure; (b) exit by acquisition or merger with another company; and (c) exit by radical restructuring. All these events produce the termination of activities of the firm in its current identity. We consider the innovative resources and capabilities of the firm (Nelson and Winter 1982; Dosi 1988, Barney 1991, Teece et al. 1997) as factors influencing the decision to exit and the choice among different ways of exiting. In particular, we argue that two factors shape the relationship between innovation and exit: the nature of innovative capabilities, which can be acquired though product or process innovation, and the synergies existing between the two types of innovation. In linking innovative capabilities to the exit behavior of firms, we draw insights from formal models of Schumpeterian competition, and especially the model proposed by Nelson and Winter (1982), and the resource-based view (RBV) of the firm (Barney 1986, 1991, Winter 1987, Nelson 1991, Eisenhardt and Martin 2000).

Our study contributes to an emerging area of research that focuses on firm exit as a heterogeneous event, and points out to forms of exit that have attracted less attention in the literature on industry dynamics, than business closure, some of which in fact may signal firm success. We

\footnotetext{
${ }^{1}$ Studies in Industrial Organization with a focus on the post-entry performance of newborn firms have also shown that, at the individual level, the innovative capabilities of the founder gained through pre-entry job experience, and the motivation to start a company to introduce new products or processes, significantly contribute to the success of the firm (Vivarelli and Audretsch 1998, Arrighetti and Vivarelli 1999).
} 
explore the factors influencing the decision to exit by using a detailed classification of exit types, which includes business closure, M\&A, and radical restructuring, across a large set of firms of different type and industrial activity. Thus, we provide some insights on two related streams of the literature that focus on the processes of merger and acquisition (M\&A) and corporate restructuring. By emphasizing the role of innovative capabilities in the exit strategies of firms, we can identify the contribution of the target firm to the M\&A process (Graebner 2004, Graebner and Eisenhardt 2004), in terms of the nature of the firm's knowledge resources (Coff 1999, Ranft and Lord 2002). We also refine the view that the decision to engage in a corporate restructuring is a response to past poor performance (Hoskisson and Turk 1990, Bethel and Liebeskind 1993, Lockett and Thompson 2001). Innovation may play a role in this strategy, however, only limited evidence exists that the firms underinvesting in R\&D are more likely to engage in restructuring (Hoskisson et al. 1994).

Furthermore, we highlight the importance of process innovation, and the existence of synergies with product innovation, in shaping the decision of a firm to exit. In the strategy literature, studies on firm survival give the greatest emphasis to the consequences of product technology strategies (Banbury and Mitchell 1995, Christensen et al. 1998, Barnett and Freeman 2001, Bayus and Agarwal 2007). They devote less attention to the implications of process innovation (Doms et al. 1995, Colombo and Delmastro 2001), or to the combined effects of product and process innovation (Cefis and Marsili 2005). A possible reason for this is that process innovation is often regarded as ‘pedestrian and grubby’ (Rosenberg 1982), as a ‘second-order innovative activity, a rather dull and unchallenging cousin of the more glamorous product innovation' (Reichstein and Salter 2006, p. 653). However, process innovation, and the relationship with product innovation, is an important factor for understanding the dynamic of competition in an industry (Utterback and Abernathy 1975, Rosenberg 1982, Cohen and Klepper 1996, Reichstein and Salter 2006).

In our analysis, we consider innovation and the nature of the innovation as antecedents to an exit event, within a model that allows their effects on alternative modes of exit (business closure, M\&A, and radical restructuring), to be assessed within the same framework. We link two harmonized and comprehensive micro-economic datasets collected by the Central Bureau of Statistics Netherlands 
(CBS): the general Annual Business Register (ABR) for 1996-2003 and the second Community Innovation Survey (CIS-2), which covers the period 1994-1996. We estimate a competing-risks model in discrete time, and apply alternative specifications of the model for a sensitivity analysis. The model controls for various firm- and technology-specific conditions, which are known to be determinants of exit, such as firm age and size, and technology regime (Audretsch 1991, Sarkar et al. 2006).

We find that, in general, innovative capabilities lower the likelihood of exit by closing down the business, and this effect is strengthened by the complementarities existing between product and process innovation. The effect differs, and is conditional on the type of capabilities, for other forms of exit. Specifically, innovative capabilities in product development, in particular when not coupled with new process development, increase the probability to exit by a M\&A, while innovative capabilities, especially in process development, lower the probability that a firm exits by radical restructuring.

The paper is organized as follows. We first formulate some hypotheses on the effects of product and process innovation on modes of exit, relying on various streams of the literature that addresses the issues of firm survival, the M\&A process, and corporate restructuring. We then describe the data and the statistical method used to estimate these effects empirically. Finally, we report the results of the estimations of a competing risks model and assess its robustness, and discuss the implications of our findings.

\section{Theoretical Background and hypotheses}

Economic models of industry evolution explain the exit decisions of firms as the outcome of processes of organizational learning (active and passive learning) and market selection (Jovanovic 1982, Nelson and Winter 1982, Iwai 1984, Winter 1984, Ericson and Pakes 1995). Innovation generates asymmetries in levels of 'competitiveness' or 'fitness' of firms, which, in turn, lead to differentials in growth rates and survival probabilities. These models of industry evolution are consistent with the management literature on capabilities and the RBV of the firm (Barney 1986, 1991, Winter 1987, Grant 1996, Teece et al. 1997, Eisenhardt and Martin, 2000). This literature emphasizes that the knowledge underlying the innovation process is a strategic asset that helps the 
firm to gain a competitive advantage and, ultimately, to survive. Although these models take explicit account of innovation as a source of competitive advantage for the firm, shaping growth and exit behavior, they do not distinguish between different types of innovation, in products or in processes. In addition, they do not account for different forms of exit, they identify exit only with the cessation of production activities, equivalent, in our definition, to firm closure.

\subsection{Innovation and exit by closure}

Drawing insights from Nelson and Winter's (1982) model we relate the innovative capabilities of the firm to the decision to exit by closing down. In the model, the process of market selection is formalized through an investment rule and an exit rule, which translate the differences in profitability among firms into differential rates of growth and survival (Nelson and Winter 1982, Winter 1984). Innovative search is expressed as a random draw from a probability distribution, whose parameters reflect the underlying nature of the technology. Given this framework, a firm that, as result of its innovative (or imitative) search, draws a better technical solution than it currently achieves (a more productive technique), will experience higher profit margins, defined as the ratio between realized mark-up and production costs. As a consequence, the innovative firm will increase its gross investments and expands its market share. If profit margins or market share are persistently below a certain minimum threshold, the firm will exit the market (Nelson and Winter 1982, Winter 1984).

While the model assumes a homogenous product and price in the market, it can be argued that the effects are similar for product and process innovations. The introduction of a process innovation, in the form of either incremental or radical improvements to the production process, helps the company to reduce the average costs of production and increase profit margins (Cohen and Klepper 1996). The introduction of new products or new product features allows the firm to gain a temporary monopoly power in the market, and produces higher profit margins since customers are willing to pay higher price for a new product or a better quality existing product (Teece 1986, Cohen and Klepper 1996). As the realized profit margin of the firm increases through the effect of lower production costs or a higher price, the innovative firm will expand its investments and grow its market share with 
respect to competitors. Under these conditions, the probability of the product or process innovator closing down business will decrease (Nelson and Winter 1982, Winter 1984). We can state:

Hypothesis 1a: Innovative capabilities, in product development or in process development, decrease the probability of a firm exiting through closure.

Process innovation is also interrelated with product innovation (Pisano 1997, Hatch and Mowery 1998). The development of a new product may require significant changes to the manufacturing process; also, innovations in production processes can trigger relevant improvements to product features and product quality. Further, the existence of complementarities in strategies (Milgrom and Roberts 1995, Mohnen and Roller 2005, Cassiman and Veugelers 2006), and synergies in resources (Barney 1991), generate additional economic benefits for the firm engaged in both product and process innovation (Athey and Schmutzler 1995).

Hypothesis 1b: The interaction of innovative capabilities in product and process development decreases the probability of a firm exiting through closure

\subsection{Innovation and exit by $M \& A$}

The Industrial Organization literature emphasizes that M\&A increases market share and productivity, through the reconfiguration and change of control of assets (McGuckin and Nguyen 1995, Caves 1998). In this tradition, research focuses on the financial, managerial and tangible assets of the firms involved in M\&A processes (Powell 1997, Astebro and Winter 2001). In contrast, research on M\&A following the knowledge-based view of the firm emphasizes the transfer of knowledge as an intangible asset, from acquired to acquiring firm, as a motive for takeover (Granstrand and Sjôlander 1990, James et al. 1998, Coff 1999, Ahuja and Katila 2001, Ranft and Lord 2002, Capron and Mitchell 2004). In this perspective, M\&A is a strategy for large firms to obtain resources and capabilities that are otherwise difficult to transfer or to build in-house, as a vehicle to purchase 
absorptive capacity externally (Cohen and Levinthal 1990). In a study of M\&A activity in Finland, Lehto and Lehtoranta (2004) observe that a larger stock of R\&D capital enhances the probability of a firm being acquired in non-processing industries (Lehto and Lehtoranta 2004). Fontana and Nesta (2009) find that firms in the Local Area Networking switch industry are more likely to be acquired the closer they are to the technological frontier. Similarly, an exit by M\&A is more likely to occur when public Internet-related firms hold high value patents prior to the IPO (Cockburn and Wagner 2010), and for new firms introducing innovative products in low-tech industries (Cefis and Marsili 2011).

Overall, firms with higher value knowledge capital are more likely to become the targets of the M\&A process. At the same time, the success of the M\&A process in the pre- and post-acquisition stages is highly dependent on the nature of the resources to be transferred from the target to the acquiring firm. Intangible assets are more difficult to transfer than tangible assets (Coff 1999), especially if they consist of tacit and socially complex knowledge (Ranft and Lord 2002). However, those attributes that can undermine the successful implementation of the acquisition process are often the same attributes that motivate the decision to buy in assets via an acquisition in the first instance (Ranft and Lord 2002). When considering the nature of knowledge involved in process and product innovation, the rationale to transfer knowledge in an embodied form, in particular through M\&A, will be greater for process than product innovation, as process innovations are less likely to be sold in disembodied form, for example through licenses, to other firms (Cohen and Klepper 1996), However, the screening, transfer and integration of knowledge related to process innovation can pose greater obstacles than for product innovation. Following the insights in Coff (1999) and Ranft and Lord (2002), we propose three reasons for this: compared to product innovation, process innovation is (i) less visible and more difficult to measure; (ii) more tacit and embedded in the environment in which it was developed; and (iii) more incremental, or less lumpy in scale.

Visibility. Information on intangible assets that is available in the financial statements of firms, is not as accurate or complete as the information on physical capital, making more difficult for a potential acquirer to measure and value the intangible assets of a target firm (Coff 1999). Process innovations often consist of improvements to production methods, introduced by shop floor workers, 
as a result of informal problem solving (Reichstein and Salter 2006). New products, on the other hand, tend to be the outcome of dedicated R\&D projects, carried out in laboratories, with more explicit and accurate financial records. Process innovations attract less strategic attention in the firm and involve less management decision-making than product innovation (Rosenberg 1982, Pisano 1997). In fact, 'many of the process innovations firms make are "silent”' (Reichstein and Salter 2006, p. 654). Furthermore, while firms can benefit from deliberately disclosing new products or new product features through patents or launching them in the press or at trade fairs, they tend to adopt a strategy of secrecy to protect new processes from imitators (Levin et al. 1987). As process innovation is less visible and more difficult to measure than product innovation, information asymmetries between sellers and buyers will be greater. Sellers will find it more difficult to identify and fully appreciate the novelty of their internal processes; doing due diligence and making accurate estimates of the value of their process innovations can be challenging. Potential buyers will find it more difficult to screen and identify possible targets, and to assess the value of a company they might want to bid for.

Embeddedness. In the M\&A process, the transfer of intangible resources is much more uncertain than the transfer of tangible resources (Coff 1999). It is hard to predict which intangible assets persist through the acquisition process, or can be transferred effectively from seller to buyer. A buyer may be able to assess possible synergies from integrating the resources of the acquired firm only after the acquisition process has taken place (Coff 1999). These problems become critical when knowledge is tacit and socially complex, dependent on a set of internal and external relationships specific to the target firm (Ranft and Lord 2002). Similar problems arise for the transfer of process innovation. Improvements in production processes are mostly the outcome of 'learning by doing' and 'learning by using' and rely on the experience and knowledge accumulated by individuals over time (Reichstein and Salter 2006). When new processes are moved from a dedicated development laboratory (like in semiconductors) to the manufacturing environment a significant amount of knowledge is lost (Hatch and Mowery 1998). Disruptions occur in existing practices and routines as engineering time is reallocated away from current operations to solve problems that emerge in the implementation of the new process technology (Hatch and Mowery 1998). These effects are even more likely to emerge in 
the transfer (via a M\&A) of process technology, between different organizations. Potential buyers may be unwilling or incapable of changing their own internal processes to integrate the newly acquired processes, if this means that scarce engineering resources and managerial attention (Ranft and Lord 2002) will be diverted from the acquirer's current operations to the new tasks.

Magnitude. In an acquisition, potential buyers are attracted more by assets that are 'important lumpy or discrete' (Caves 1998, p. 1963), which are expected or perceived to have a greater impact on the productivity of the acquiring firm. Process innovations generally consist of small and incremental improvements (Reichstein and Salter 2006). Although they may have significant effects in terms of improving productivity, they are granted low status in the innovation process, 'involving little of the great events that characterize product innovation' (Reichstein and Salter 2006, p. 653). As a consequence, process innovations can represent a less attractive target for acquisition than product innovations. Acquiring firms may focus on product innovations in their search for possible target firms, especially if it is part of a systematic growth strategy. As a result, potential buyers are likely to have more experience and capabilities in managing acquisitions for product innovation, but be less familiar with the selection and acquisition of new processes.

Overall, we expect that, while innovative firms are generally attractive as the targets for M\&A, the difficulties involved in assessing, transferring and integrating knowledge resources accumulated through new process development, compared to those accumulated in new product development, are an obstacle to an M\&A. Hence, we can formulate the following hypotheses:

Hypothesis 2a: Innovative capabilities in product development increase the probability of a firm exiting through M\&A.

Hypothesis 2b: Innovative capabilities in process development decrease the probability of a firm exiting through $M \& A$.

Because of potential complementarity between product and process innovation, and having assumed 
in Hypothesis 2a and 2b that product and process innovations influence exit by M\&A in opposite directions, we expect that the positive effect of product innovation on exit by M\&A is greater when it is combined with a low level of process innovation. In other words firms with the highest probability to be acquired are those that carry out product innovation and no process innovation. One possible explanation is that these firms have a valuable product idea, but they lack the complementary assets necessary to adapt production processes. If the complementary assets are specific to the innovation and require high sunk costs, a firm may decide to sell the company, and the innovation, instead of competing in the product market (Teece 1986, Gans and Stern 2003). Fontana and Nesta (2009, p.303) in their study of product innovators observe that the "good, but not-good-enough innovators are more exposed to acquisition.” Our argument is that firms are in a similar position when they are not able to develop capabilities in process innovation complementary to their new products.

Hypothesis 2c: The lack of innovative capabilities in process development increases the probability that a firm with product innovation capabilities exits by M\&A.

\subsection{Innovation and exit by radical restructuring}

Finally, we consider exit due to corporate restructuring. Hoskisson and Turk (1990, p. 459) define corporate restructuring ‘as a major change in the composition of a firm's assets combined with a major change in its corporate strategy'. Corporate restructuring implies a radical transformation of the firm's identity - both its control structure and its strategic dimension. In the process of corporate restructuring, the overall organization is broken up, with several units involved simultaneously: some parts of the company are closed down, while others are divested through spin-offs, or sold to other parties (Hoskisson and Turk 1990). In general, the decision to restructure is seen as a direct response by management to poor performance and past mistakes, often triggered by a critical event, such as the threat of a hostile takeover (Hoskisson and Turk 1990, Bethel and Liebeskind 1993, Gibbs 1993, Lockett and Thompson 2001). The factors leading to such a decision may differ. According to agency theory, a decision to restructure is more likely if, in pursuing growth, managers have over-expanded 
or over-diversified the firm, without adding to its market value, thus failing to optimize the interests of shareholders (Hoskisson and Turk 1990). Furthermore, if large firms have grown relaying on acquisitions, heavily engaging in the market for corporate control, they may have shifted focus to short-term goals, and diverted attention and resources away from innovation projects inside the firm (Hitt et al. 1996). It has also been observed that the decision to restructure - especially in high-tech industries (Markides 1992), can be motivated by an explicit change in the firm’s innovation strategy (Hoskisson et al. 1994). By radically transforming the firm, managers try to free the otherwise misallocated resources in an attempt to achieve innovation and revert a period of poor performance.

Thus, in general, firms that are likely to go through a radical restructuring are large, highly diversified firms, that in the past have invested poorly to build innovative capabilities. Accordingly we hypothesize that past innovation lowers the probability to exit by radical restructuring. In addition, we argue that this effect is stronger for process than product innovation. When in trouble, most firms, in the attempt to reverse a period of declining performance, will focus on short-term financial objectives and will reach out for cost-cutting measures (Hitt et al. 1996). Managers will be less willing to invest in innovation projects that are perceived as highly risky, and which require long time before yielding any return (Hitt et al. 1996). This applies especially when time is limited due to an external threat, such as an imminent hostile takeover. By implementing a process innovation, the firm trying to stave off an external threat in a period of poor performance, can reduce the costs of production significantly, in the hope of remaining in the market. It is less likely that firms under threat will embark on a research project to develop a new product, which would require considerable resources (technology, marketing, organization, financial, time), and would have uncertain outcomes. A cost-cutting strategy, through process innovation, may provide more immediate returns compared to the long-time impact of product innovation. Therefore, a firm with relatively stronger capabilities in process innovation than in product innovation will be able to react through cost reductions to more immediate external threats. This will reduce the need for a radical restructuring. Furthermore, because of complementarities between product and process innovation, firms that lack both types of innovative capabilities will be in especially weak positions, which may make their radical 
transformation imperative. Hence, we assume:

Hypothesis 3a: Innovative capabilities, especially in process development, decrease the probability of a firm exiting the market through radical restructuring

Hypothesis 3b: The interaction of innovative capabilities in product and process development decreases the probability of a firm exiting the market through radical restructuring

\section{Statistical methods}

The main aim of our empirical analysis is to model the effects of firms' innovative activities on different modes of exit. Specifically, we consider three types of events that induce firm exit: business closure; M\&A; and radical restructuring. Because the antecedents to these three types of exits may be different, we choose a model that has the potential to distinguish among these events. We estimated a competing risks model that enables the pursuit of two aims: (i) to analyze the factors that influence the probability of an event occurring (in our case the event is firm exit); (ii) to distinguish the effects of these factors on the event resulting from different modalities (business closure, M\&A, radical restructuring). The exit of a firm is an event that occurs in continuous time, but is reported in discrete time, in our case monthly. We therefore apply the discrete-time method proposed by Allison (1982) and extended by Jenkins $(1995,2004)$ to estimate the model's parameters taking account of the discrete nature of our data. The model is based on the definition of a latent variable representing the uncensored failure time $T_{j}$ for each specific modality $j$ of the exit event, for $j=1, \ldots, k$, namely business closure, M\&A, and radical restructuring. The observed failure time $T=\min \left\{T_{j}\right\}_{j}$ is censored for the firms that survive throughout the period. The discrete-time hazard rate specific to the exit mode $j$ for firm $i$ is defined as

$$
h_{j i}(t)=\operatorname{Pr}\left\{T_{j i}=t \mid T_{j i} \geq t ; X_{i t}\right\}
$$

where $X_{i t}$ is a vector of the explanatory variables. Consequently, the probability of observing a spell of length $t$ for a specific type of exit $j$ is: 


$$
p_{j i}(t)=\operatorname{Pr}\left\{T_{j}=t\right\}=h_{j i}(t) S_{i}(t-1)
$$

where $S(t)$ is the discrete time survivor function, which can be written as

$$
S_{i}(t)=\operatorname{Pr}\left\{T_{i}>t\right\}=\prod_{s=1}^{t}\left[1-h_{i}(s)\right]=\left[1-h_{i}(t)\right] S_{i}(t-1)
$$

where $h_{i}(t)=\sum_{j=1}^{k} h_{j i}(t)$ is the hazard function for any type of exit equal to the sum of the single hazard functions, specific to the various types of exit, assuming independent competing risks. Combining (3) and (2) leads to:

$$
p_{j i}(t)=\operatorname{Pr}\left\{T_{j i}=t\right\}=\frac{h_{j i}(t)}{1-h_{i}(t)} S_{i}(t)
$$

The contribution to the likelihood of the ith firm with observed spell $t$ (uncensored or censored) is

$$
L_{i}=\prod_{j=1}^{k} \operatorname{Pr}\left\{T_{j i}=t\right\}^{\delta_{j}} \operatorname{Pr}\left\{T_{i}>t\right\}^{1-\sum \delta_{j}}
$$

where $\delta_{j i}$ is a dummy variable set equal to 1 if the ith observation of $T_{j}$ is uncensored and equal to 0 if it is censored; the observation is considered as censored when the firm either does not exit during the considered time period or exits by a means different from $j$.

Because in discrete time, the model cannot be estimated by separate duration models, each formulated for a certain type of exit and corresponding censoring indicator $\delta_{j}$, a new variable $y_{j i, t}$ needs to be created. This is set equal to 1 if firm $i$ experiences an exit of type $j$ at time $t$, and equal to 0 otherwise, with $\delta_{j i}=\sum_{s=1}^{t} y_{j i, s}$. For the modified panel data set, following Allison (1982), we apply a generalized form of the logistic function for the hazard rate, which is a common choice for a nonproportional hazard specification:

$$
h_{j i}(t)=\frac{\exp \left\{\beta_{j}^{\prime} X_{i t}\right\}}{1+\sum_{j=1}^{k} \exp \left\{\beta_{j}^{\prime} X_{i t}\right\}}
$$

In this case the log-likelihood is equivalent to the multinomial logit model, in which the unit of analysis is the time spell.

We conducted a sensitivity analysis of the assumptions related to the continuous-time hazards that yield the observed duration times, using the complementary log-log model. An alternative 
specification for the hazard function reported in Eq. (7) is the complementary log-log form (Jenkins 1995, 2004):

$$
h_{j i}(t)=1-\exp \left\{-\exp \left[\beta_{j}^{\prime} X_{i t}\right]\right\}
$$

The 'complementary log-log model' is equivalent in discrete time to a continuous-time proportional hazard model, in which failure times are grouped in unit intervals and registered only at the end of each time period (Prentice and Gloeckler 1978).

Finally in order to test for possible effects of unobserved heterogeneity (or frailty), for each exit form, we estimate a discrete-time duration model both in the logistic and complementary log-log form, with a frailty term Normally distributed. The test is based on the null hypothesis that the 'rho' statistic - the ratio between the heterogeneity variance to one plus the heterogeneity variance - is equal to zero. If the null hypothesis cannot be rejected, one can conclude that unobserved heterogeneity is of no significant consequence for the estimated model coefficients (Jenkins 2004).

\section{Data and measurements}

This study uses two micro-economic databases collected and managed by the CBS: the ABR and the CIS-2 for the Netherlands. Firm data on innovation are drawn from the second national survey of innovation in the Netherlands, based on the core Eurostat CIS (CBS, 1998). CIS surveys for Europe adopt innovation definitions from the OECD (OECD-EUROSTAT, 1997) and have been conducted since the early 1990s, with a periodicity of four years for most countries. An increasing number of studies have been using CIS data to measure innovation, its determinants and effects, both at firm level and economy-wide (Cassiman and Veugelers 2002, Mairesse and Mohnen 2002, Laursen and Salter 2006, Leiponen and Helfat 2010; for a survey of studies using CIS data see Hall and Mairesse 2009). The CIS-2 for the Netherlands was administered in 1997. It provides information on innovative activities and performance in the period 1994-1996, for a large sample of firms with at least 10 employees. The firms were extracted from those present in the ABR in 1996 in order to constitute a stratified random sample, based on size class, region and industry sector at the 2-digit standard industry classification (SIC) code level. For the manufacturing sector, the number of respondents to 
CIS-2 was 3,299 firms, with a response rate of 71 per cent. Therefore the CIS-2 is a representative and comprehensive sample of the population of firms above 10 employees.

We match the data from respondents to CIS-2 with data from the ABR for 1996, from which the CIS-2 sample was extracted, obtaining a final dataset of 3,275 firms. This allows us to combine firm level data on innovation for a large set of firms, with data on exit and other covariates (such as age, size and sector) for the same set of firms, derived from the ABR.

The ABR comprises annual records for all firms that are registered for fiscal purposes in the Netherlands. The annual dataset is constructed longitudinally: for each firm present in the population at a certain year, it reports the month that the firm was first included in the register and the month that the firm was eventually dropped from the register. Its comprehensive nature and fiscal purpose means that the dates of inclusion and exclusion in the register are very close approximations of actual dates of market entry and exit. Note that the definition of entry and exit is based on the entire population of firms: exits exclude firms whose sector of activity changes, which are regarded as continuing firms. The population of firms includes self-employment, that is, firms with 0 employees. For the manufacturing sector in 1996 the ABR includes 61,177 firms.

The annual ABR allows mode of exit to be identified. We distinguish three categories. Exit by failure, which includes firms dropped from the register due to the termination of activities (either voluntary or by bankruptcy). ${ }^{2}$ The category exit by $M \& A$ includes firms that are merged with other(s) firms resulting in a firm with a new identity, and firms that are acquired by other firms, where the latter maintain their identity. ${ }^{3}$ The third category of exit by radical restructuring accounts for when a firm is decomposed into several units (some of which may reappear in the register as new firms, and some of which may be sold to other firms), or when the firm undergoes a major transformation, which results in a change to its legal or economic identity. By combining this information from the annual

\footnotetext{
${ }^{2}$ The data do not allow us to distinguish between exit as a result of bankruptcy and exit due to voluntary closure. However, we assume that these two types of exits can be considered equivalent when compared to the other exit forms considered in the study. In general, the ownership of a firm does not close a profitable firm without selling the whole or part of the firm, which would be recorded in our data set, respectively, as acquisition or radical restructuring.

${ }^{3}$ We use the terms M\&A and acquired interchangeably. We do this for convenience, but it reflects the fact that the majority of M\&A are acquisitions and rarely real mergers, involving two previously independent firms losing their identities to become (with equal shares, $50 \%$ ) a completely new firm.
} 
ABR datasets for 1996 to 2003, we can follow the sequence of exits up to December 2003, for each type of exit.

Note that our dependent variable (survival time before the occurrence of an exit event) and our independent variables are drawn from two separate data sets: respectively the ABR and the CIS-2. The sources and collection of these two data sets are completely independent. The ABR is a product of a national data tracking exercise for fiscal purposes, which is conducted in a systematic and continuous way by the CBS. The CIS is a European-level survey administered periodically (at regular intervals) by the CBS, which was designed by Eurostat. There is no interdependence in the design of the two databanks. Our empirical analysis is based, therefore, on the combination of two different and independent sources of data, implying that there are no common method bias problems.

Also, the dependent and independent variables are observed at a long time distance. The independent variables are defined as initial conditions, after which the occurrence of an exit event, defining our dependent variable, is recorded. The time distance between an identified exit event and the measure of the explanatory variables is very high. This time lag minimizes the risk of endogeneity.

\section{$<$ Insert Table 1 here >}

Table 1 presents composition and average employment for the set of firms from the CIS-2 and the population from the ABR, according to mode of exit, for the period 1996-2003. Because only firms with 10 or more employees are included in the CIS-2, we also report the statistics for the only ABR firms with the same employment threshold. ${ }^{4}$ The percentage of continuing firms is higher in CIS-2 than for the whole population in the ABR, and for the set with more than 10 employees. This is due to the effect of size on firm survival. Indeed, as previous work using the same datasets shows (Cefis and Marsili, 2005, 2006), survival probabilities increase with firm size. When we look at exit modes we can see that the number of firms that exited the market due to failure is much higher for the whole ABR than for the other two samples. This is because micro firms (less than 10 employees) are more

\footnotetext{
${ }^{4}$ For CIS-2, a few countries (e.g. the Netherlands, Finland and the UK) set a threshold of 10 employees; for all the other European countries the threshold is of 20 employees.
} 
likely than larger firms to exit the market and, in particular, to exit due to failure. Furthermore, micro firms are obviously much less likely to undertake a restructuring process and are much less likely to be involved in M\&A. The average number of employees in firms that close down is six, in those that exit by M\&A it is around 34, and in those that exit by restructuring it is 227 .

\subsection{Dependent variable}

The duration variable is the length of time from January 1996 to time of exit from the ABR. The exit event is differentiated into: failure, M\&A and radical restructuring. Survival time is measured in months and is censored to the right for firms that survived to December 2003, the last month for which date of exit and exit mode for firms listed in the ABR are available.

\subsection{Independent variables}

In the CIS-2 dataset, we distinguish the firms that introduced new or improved products or processes in the 1994-1996 period (defining them innovators) and the firms that did not innovate in the same time period (non-innovators). A non-innovator is a firm that either has not engaged in innovative activities in that period, or conducted an innovative project that was unsuccessful or incomplete at the end of 1996 . The ability of a firm to innovate is then expressed by a dummy variable that is equal to 1 if a firm is an innovator and to 0 , if the firm is a non-innovator. Beyond the general ability of a firm to innovate, we consider that the nature of the innovation, product or a process, may shape its effects on hazard rates, leading to divergent effects for different types of exit. To measure this, we introduce a dummy variable that is equal to 1 if a firm is a 'product innovator', that is, if it has introduced a new or an improved product in the period 1994-1996, and equal to 0 otherwise, and a dummy that is equal to 1 if the firm is a 'process innovator', that is, if it has introduced a new or an improved process in the period 1994-1996, and equal to 0 otherwise.

In order to single out the interaction effect of product and process innovation, from the individual and specific influences of the two types of innovation we create another set of dummy variables. In line with studies that have examined complementarities between different types of innovative 
activities or strategies (Mohnen and Roller 2005, Cassiman and Veugelers 2006), we use mutually exclusive categories. The first dummy variable identifies 'only product innovator', and is set at 1 if a firm introduced only a product innovation in 1994-1996 and 0 otherwise. The second dummy for 'only process innovator' is equal to 1 if the firm introduced only a process innovation, and the third dummy, 'product and process innovator', is for firms that introduced both a product and a process innovation. From the sample of 3,275 firms in CIS-2, 42.7\% of firms introduced both a product and a process innovation; $14.8 \%$ of firms introduced only a product innovation and 5.8\% of firms introduced only a process innovation. Non-innovators constituted $36.6 \%$ of the total.

\subsection{Control variables}

It is a well-known empirical fact that likelihood of survival increases with firm age and size (Evans 1987, Dunne et al. 1988, Audretsch and Mahmood, 1994, Geroski, Mata, and Portugal 2010). For economists, large firms experience lower risk to exit because they are likely to operate closer to the minimum efficient scale of production than small firms (Audretsch and Mahmood, 1994) or because have better knowledge of how efficient they are, having been in the market for a longer time period (Jovanovic 1982). For organizational ecologists, novel organizations face liabilities of smallness and newness due to lack of resources and legitimacy, which expose them to higher risks of exit (Freeman, Carroll, and Hannan 1983). In our model, we control for firm age and size. From the ABR data, we define firm age computing the number of months of existence from the date of entry, until January 1996, the beginning of the period of observation. Firm size is measured as the number of employees in 1996, obtained from the ABR. Since both variables are highly skewed, we take the natural logarithms.

It has been observed that the effect of firm size on exit is non-linear: beyond a certain threshold the probability to exit starts to increase, as firms grow larger (Evans 1987, Hall 1987). There is also evidence that the likelihood of an acquisition decreases with increasing firm size (Powell 1997), with some non-linearity in the relationship, as takeovers seem to concentrate at the center of the size distribution (Dunne and Hughes 1994). While aging lowers organizational mortality this effect as well 
reaches a threshold, beyond which the risk of exit starts to increase as firms age (Evans 1987). However, some studies indicate that mortality rates (however high at birth) can increase in the very first few years of life, before declining (Audretsch, Santarelli, and Vivarelli 1999). This inverted-U shape signals the existence of a "liability of adolescence" as newly born firms are not immediately selected out by market forces, but are given some time by stakeholders to prove their worth (Bruderl and Schussler 1990). To account for the potential non-linear relationship of size and age with the form of exit, we include the squared terms for the two variables (in logarithms) into all our models. We also add the product of the logarithm of size and the logarithm of age, to account for a possible interaction between firm age and size in shaping firm exit (Evans 1987).

Finally, we control for differences in the nature of the technology environment, which can shape exit conditions in an industry (Sarkar et al. 2006), using Pavitt’s (1984) taxonomy. This captures some fundamental differences in the characteristics of the innovation process (e.g. its sources, nature and direction of change) that distinguish firms operating in different industrial sectors. We construct a dummy for each of Pavitt’s four categories of firms: science-based firms (Pavitt 1), scale intensive firms (Pavitt 2), specialized suppliers (Pavitt 3), and supplier dominated firms (Pavitt 4). The last category is the reference group in our estimates.

All the independent and control variables are treated as initial conditions, which are held constant during the period of observation of exit events. The time dimension is entered in the specification of the econometric model in parametric form, using the logarithm of the spell duration (LnTime). This is equivalent to assume that the baseline hazard varies monotonically with time.

\section{$<$ Insert Table 2 about here >}

Table 2 illustrates the distribution of events across firms with different innovative capabilities. The occurrence of exit by closing down of activities concentrates in firms that do not innovate, while an opposite pattern characterizes exits by M\&A, which concentrate in firms that do innovate. When looking at the correlation matrix in Table 3, the variables 'product innovator' and 'process innovator' are, as expected, highly correlated with the 'product and process innovator' variable. These two sets of variables have been included in alternative specifications of the model, and, overall, the correlation 
coefficients do not suggest the presence of multi-collinearity problems in the model estimation.

$<$ Insert Table 3 about here >

\section{Results}

Table 4 reports the estimated coefficients of the competing risks model using the multinomial logit form; this is equivalent to assuming a logistic-type hazard function for each exit event, as in equation (7). We use three different versions of the model, each corresponding to an alternative set of dummies used to express innovation in a firm, while the control variables remain the same for all three models.

\section{$<$ Insert Table 4 about here $>$}

In model 1 we chose as a proxy for the innovative ability of the firm, the general dummy for the firm's being an innovator. In this case, innovation has a negative and statistically significant effect on the probabilities of exit due to failure and to restructuring, while the effect is statistically significant, but positive for the probability of being acquired. In model 2, we replace the general innovator variable with the product and process innovator dummies, to distinguish between the roles of different types of innovation. We observe that the results are differentiated across the different modes of exit, according to the type of innovation. The introduction of either product or process innovations significantly decreases the probabilities of exit due to failure (Hypothesis 1a). This is the only mode of exit where the type of innovation does not matter; it is having innovated that is important. However, the probability of exiting as the result of an M\&A is significantly and positively affected by involvement in product innovation (Hypothesis 2a), while the effect is not statistically significant for process innovation (Hypothesis $2 \mathrm{~b}$ is not supported). Firms that can demonstrate an ability to introduce new products in the market have a higher chance of becoming the targets of M\&A processes. In the case of exit by radical restructuring, on the other hand, the probability is lower for firms that have introduced process innovations (Hypothesis 3a); the effect is not statistically significant for product innovation.

Finally, in order to disentangle the individual roles of product and process innovation, from their combined effect, model 3 introduces three dummies that identify firms with product innovations only, 
with process innovations only, and those with both product and process innovations. The coefficients of these dummies confirm and reinforce the previous results. Being an innovator, regardless of the type of innovation, is what really matters in terms of reducing the probability of the firm closing down activities. Firms that have innovated in products but not in processes are more likely to exit by M\&A. Lack of process innovation reinforces the positive effect of product innovation on the probability of exit by M\&A (Hypothesis 2c). When considering firms that perform both process and product innovation, these have lower probabilities of exit by closure of activities (Hypothesis 1b) and of exit by radical restructuring (Hypothesis 3b).

In estimating the various specifications of the model, we account for a number of control variables. It should be noted that the statistical significance and the sign of the coefficients of these variables do not change if we use different proxies for innovation. In other words, the coefficients are relatively invariant across models 1,2 , and 3 . However, different effects of these same covariates can be observed across the various modes of exits.

Firm age and firm size both have a negative and statistically significant effect on the probability of exit through failure and M\&A. In contrast, firm size has a positive and statistically significant influence on the probability that a firm exits because of restructuring. The square of age is significant and positive only for exit as a result of failure, while the coefficient of the square of firm size is statistically significant for all three types of exit, but the sign varies: it is positive in the case of exit due to failure and M\&A, and negative in the case of exit due to restructuring. The larger the firm, the lower the probability of exit due to failure or M\&A and the higher the probability of exit due to radical restructuring; but the magnitude of these effects decreases with firm size. The interaction between age and size is significant only for exit due to failure. The sign is positive, indicating that although firm size and age reduce the probability of exit due to failure, this probability declines less sharply for firms that are, respectively, older and larger. Firms may become too large or too old to survive.

In order to control for sectoral specificities, we estimate the models using Pavitt's taxonomy and SIC at the 2-digit level. The results show that the coefficients of the dummies for Pavitt sectors are 
significant only in the case of exit due to M\&A. Belonging to the science-based (Pavitt1) and specialized supplier (Pavitt3) sectors decreases the probability of exit from the market due to being acquired by another firm.

When we apply the dummies for the 2-digit sector in which the firm is active, rather than the Pavitt dummies, the results generally do not change. ${ }^{5}$ The innovation proxies retain their significance and their effects on the probabilities of different types of exit change neither in direction nor magnitude. This is also the case for the coefficients of the control variables for age and size, and their interaction. The effects of belonging to a specific sector are mixed; there are no regularities or empirical patterns that emerge from the analysis in contrast to what happens when we consider Pavitt's taxonomy. That is, the dummies for the 2-digit sectors do not identify sectors where the probabilities of exiting the market for particular reasons significantly decrease or increase.

\subsection{Sensitivity analysis}

The analysis in this section assesses the sensitivity of the estimates with respect to different hypotheses about the hazards in continuous time, which generate the failure times registered at discrete time intervals. Table 5 presents the estimates of the coefficients of the competing risks model under the assumption of a complementary log-log specification for the hazard function, according to equation (8).

\section{$<$ Insert Table 5 here $>$}

Table 5 shows that the estimated coefficients of the complementary log-log model maintain statistical significance for the same set of variables as in the case of the logistic specification of the hazard functions. The estimated values of the coefficients for the two cases presented in Tables 4 and 5 are remarkably similar. This suggests that monthly intervals in the observation of firms' exits are quite fine-grained, and different assumptions about the behavior of the continuous hazards within intervals do not lead to substantially different results.

Finally, for all specifications, logistic and complementary log-log, we estimate a frailty model to

\footnotetext{
${ }^{5}$ Available on request.
} 
assess possible biases dues to the effects of unobserved differences among firms (Table 6). The null hypothesis that the 'rho' statistics is equal to zero could not be rejected at 10 per cent level for any mode of exit, indicating that frailty is not statistically significant.

\section{$<$ Insert Table 6 here $>$}

\section{Discussion and conclusions}

Our findings show that, in general, the ability of a firm to innovate is an important determinant of its exit decision. Firm exit is often seen as a failure on the part of the firm. This study strengthens the common view that innovation enhances firm performance. We find that firms that have innovated are less likely to be forced to close down their activities. This effect persists for a number of years after the achievement of the innovation, and is independent of the type of innovation, whether it relates to new products introduced into the market or new processes implemented within the firm. We also find that innovative firms are less likely to engage in radical restructuring, which represents an exit of the firm in its current identity. Our results suggest that in situations of distress and threat, which may trigger management decision to undertake corporate restructuring, innovative capabilities help the firm to adapt while maintaining its core identity. Ultimately, innovation helps firms to survive. However, exit is not necessarily a sign of failure; it can be an explicit strategy of the firm. Our findings suggest that innovation opens alternative pathways for the firm to exit, in the form of an exit by merge or acquisition. Innovation makes the firm more attractive to potential acquirers.

An important finding from our study is that the nature of innovative capabilities, and the synergies that originate in developing both product and process innovation capabilities, play a role in shaping the exit behavior of firms. We find that product and process innovation, both separately and in combination, reduce the risk of closing down activities. We also observe that process innovation especially lowers the likelihood of the firm undertaking a process of radical restructuring, while product innovation, particularly if not combined with process innovation, increases the probability to exit by M\&A. Thus, product innovation results to be more important in the decision to exit through acquisition, while process innovation is relatively more beneficial to maintain a firm's portfolio of 
businesses and identity. The results also suggest that firms gain advantage from carrying out both product and process innovations, compared to specializing in one or the other type: their chances of survival are higher and they can rely on a broader range of exit strategies. This implies that there are complementarities between product and process innovation in relation to firm survival and exit behavior.

Consistent with the RBV of the firm, our results confirm that innovation represents a resource and a capability that help the firm to acquire and maintain competitive advantage. We find that capabilities in new product development are more valuable for a strategic exit, and the capture of economic rents in the 'market for firms'. For firms that want to sell out to another company, capabilities in new product development are a clearer signal of the value of the company to potential buyers. For acquirers, accessing capabilities in new product development in the target firm is perceived as a source of greater opportunities for improving performance. Also, these capabilities are easier to transfer and integrate into the existing acquiring organization. Conversely, we find that capabilities in new process development are more valuable for sustaining a business in the product market. They enable the firm to transform and incrementally improve internal practices and processes, which in turns enables continuing survival and ability to compete in the market. Such firms are also better equipped to change organically, to adapt to external situations of distress or critical events, which otherwise would demand a radical transformation of their business portfolio and identity.

Our results shed further light on the relationship between innovation and firm dynamics. In the Product Life Cycle model (Utterback and Abernathy 1975, Gort and Klepper 1982, Klepper 1996), the distinction between product and process innovation is essential to explain firm dynamics. In particular, the survival of firms depends on the different roles played by product and process innovation in enhancing the competitive advantage of firms at various stages of evolution of a new technology. Prior research within this approach shows that firms entering a new product market with the latest product technology or new product architecture, have a greater chance of survival than do entrants that do not adopt such strategies. However, entrants are unable to benefit from process innovation because of their small size. Large incumbent firms are those that benefit from increased 
productivity due to process innovation. Our study further emphasizes the importance of process innovation. After controlling for differences in firm size, process innovation appears to be as important as product innovation in terms of increasing firms' survival prospects.

In distinguishing among different forms of exit, our results provide insights into the antecedents to the M\&A process. As contended by the resource-based view of the firm, our study confirms the importance of innovation, as a resource and capability of the target firm in the M\&A process. In the context of the M\&A theory, the result that product innovation is more conducive to exit by M\&A, than process innovation would suggest that the problem of transferring and integrating the (tacit) knowledge associated with process innovation during the acquisition implementation process, may carry more weight in the decision to acquire than the value of gaining this knowledge.. The value of product innovation is greater, more visible and easier to capture for an M\&A.

Finally, our results support the view that access to complementary assets can influence exit behavior (Teece 1986, Gans and Stern 2003). Process innovation can be considered a form of complementary assets: once a new product idea has been developed significant investments are needed to enter large scale production, and to distribute and sell to customers. This often requires specific changes in internal production processes. Accordingly, we observe that the decision to sell the company is most likely when firms have introduced new products but do not have the resources and capabilities to introduce complementary process innovations. These conditions can attract the attention of potential acquirers that are better able to exploit the target's new product idea given their particular resources and complementary assets (Gans and Stern 2003). These considerations raise the question about the positive or negative connotation of an M\&A, when driven by innovation in the target company. Our study indicates that the decision to sell a company may be ultimately driven by the lack of complementary assets, in firms that do have the ability to generate innovative products. A limitation of our analysis is that it does not measure the economic value an exit. A direction for further research would be to extend the analysis of the exit choice set to include measures of performance in order to better capture the difference between successful and unsuccessful exits.

The existence of efficiencies in the M\&A process is a core argument in competition policy: they 
can be used, according to the current European Commission Merger Guidelines, as defense when a merger is challenged in a case (Cefis et al 2007). In particular dynamic efficiencies, which take place when acquiring firms gain in innovative capabilities through knowledge transfer from the acquired firms, can be called upon to balance against the loss of allocation efficiency due to reduced competition, as potential competitors with innovative products are removed from the market. Our study confirms that the innovative capabilities of the target firm do play a role in the M\&A process, but it does not allow distinguishing between the two types of efficiencies. While we focus on the resources of the acquired firm, future research could extend this type of study to combine it with the characteristics and performance implications of the acquiring firms (Cefis et al 2007), approach that could help to disentangle the different efficiency effects in the M\&A process.

Our results have implications for entrepreneurs and managers. The imperative 'innovate or die' is well know in management practice. However, some firms are also faced with the imperative to 'innovate and exit'. Which of the two is more compelling depends on the nature of the firm's innovative capabilities. For firms keen to harvest the returns from their activities by merging with or selling out to other firms, it is important to have a novel product idea that will attract the attention of potential acquirers. Such an exit strategy can be crucial for firms that do not have the resources and capabilities to support their product innovation through changes to their internal practices and processes. For firms that want to sustain their businesses over time and maintain their corporate identities, process innovation is of vital importance. These firms can achieve even greater advantage by exploiting complementarities in innovation, by matching their abilities to adapt and change processes to novel product ideas. 


\section{Acknowledgments}

The authors want to thank Thomas Astebro, Uwe Cantner, Paola Criscuolo, Bernd Ebersberger, Keld Laursen, Mariana Mazzucato, Pierre Mohnen, Dario Pozzoli, Stéphane Robin, Ammon Salter, Toke Reichstein and participants at the 2006 International Schumpeter Society Conference; the 2006 DIME (Dynamics of Institutions and Markets in Europe - Network of Excellence) workshop, Firm-Level Longitudinal Data on Economic Performances and their Determinants; the 2007 DRUID Summer Conference, Copenhagen; an October 2007 seminar at Department of Economics, University of Bergamo, Italy; a seminar at Max Plank Institute, Jena, Germany, in January 2008; and a seminar at CESPRI, Bocconi University, Milan , in February 2008, for helpful comments and suggestions. The empirical part of this research was carried out at the Centre for Research of Economic Microdata at Statistics Netherlands (CBS). The views expressed in this paper are those of the authors and do not necessarily reflect the policies of Statistics Netherlands. Elena Cefis acknowledges financial support from the University of Bergamo (grant ex 60\%, n. 60CEFI09, Dept. of Economics). 


\section{References}

Agarwal, R., Audretsch, D.B., 2001. Does entry size matter? The impact of the life cycle and technology on firm survival. Journal of Industrial Economics. 49(1), 21-43.

Ahuja, G., Katila, R., 2001. Technological acquisitions and the innovation performance of acquiring firms: a longitudinal study. Strategic Management Journal. 22(3), 197-220.

Allison, P.D, 1982. Discrete-time methods for the analysis of event histories. Sociological Methodology. 13, 61-98.

Arrighetti A., Vivarelli, M. 1999. The Role of Innovation in the Postentry Performance of New Small Firms: Evidence from Italy. Southern Economic Journal. 65(4) 927-939.

Astebro, T.B., Winter, J.K., 2001. More than a dummy: the probability of failure, survival and acquisition of firms in financial distress. Working paper. Available at SSRN: http://ssrn.com/abstract $=260949$

Athey, S., Schmutzler, A., 1995. Product and process flexibility in an innovative environment. RAND Journal of Economics. 26(4), 557-574.

Audretsch, D.B, 1991. New-firm survival and the technological regime. Review of Economics and Statistics. 73(3), 441-450.

Audretsch, D.B, 1995. Innovation, growth and survival. International Journal of Industrial Organization. 13(4), 441-457.

Audretsch, D.B., Mahmood, T. 1995. New firm survival: new results using a hazard function. Review of Economics and Statistics. 77(1) 97-103

Audretsch, D.B., Santarelli, E., Vivarelli, M. 1999. Start-up size and industrial dynamics: some evidence from Italian manufacturing. International Journal of Industrial Organization. 17(7) 965-983.

Banbury, C.M., Mitchell, W., 1995. The effect of introducing important incremental innovations on market share and business survival. Strategic Management Journal. 16, 161-182.

Barnett, W.B., Freeman, J., 2001. Too much of a good thing? Product proliferation and organizational failure. Organization Science. 12(5), 539-558.

Barney, J.B., 1991. Firm resources and sustained competitive advantage. Journal of Management. 17(1), 99-120.

Barney, J.B., 1986. Types of competition and the theory of strategy: Toward an integrative framework. Academy of Management Review. 11(4), 791-800.

Bayus, B.L., Agarwal, R., 2007. The role of pre-entry experience, entry timing, and product technology strategies in explaining firm survival. Management Science. 53(12), 1887-1902.

Bethel, J.E., Liebeskind, J., 1993. The effects of ownership structure on corporate restructuring. Strategic Management Journal. 14(S1), 15-31.

Bruderl, J., Preisendorfen, P., Ziegler, R., 1992. Survival chances of newly founded business organizations. American Sociological Review. 57(2), 227-242.

Bruderl, J., Schussler, R., 1990. Organizational mortality: The liabilities of newness and adolescence. Administrative Science Quarterly. 35(3), 530-547.

Buehler, S., Kaiser, C., Jaeger, F., 2006. Merge or fail? The determinants of mergers and bankruptcies in Switzerland, 1995-2000. Economics Letters. 90(1), 88-95.

Buddelmeyer, H., Jensen, P.H., Webster, E. 2010. Innovation and the determinants of company survival. Oxford Economic Papers. 62(2) 261-285.

Capron, L., Mitchell, W., 2004. Where firms change: Internal development versus external capability sourcing in the global telecommunications industry. European Management Review. 1(2), 157-174.

Carroll, G.R., Hannan, M.T., 2000. The Demography of Corporations and Industries. Princeton 
University Press, Princeton, NJ, US.

Cassiman, B., Veugelers, R., 2002. Spillovers and R\&D cooperation: Some empirical evidence. American Economic Review. 92(4), 1169-1184.

Cassiman, B., Veugelers, R., 2006. In Search of complementarity in innovation strategy: Internal R\&D and external knowledge acquisition. Management Science. 52(1), 68-82.

Caves, R.E., 1998. Industrial organization and new findings on the turnover and mobility of firms. Journal of Economic Literature. 36(4), 1947-1982.

CBS, 1998. The Knowledge Based Economy (in Dutch: Kennis en Economie). Statistics Netherlands, Voorburg/Heerlen, The Netherlands.

Cefis, E., Marsili, O., 2005. A matter of life and death: Innovation and firm survival. Industrial and Corporate Change. 14(6), 1-26.

Cefis, E., Marsili, O., 2006. Survivor: The role of innovation in firm's survival. Research Policy. 35(5), 626-641.

Cefis, E., Marsili, O. 2011. Born to flip. Exit decisions of entrepreneurial firms in high-tech and lowtech industries. Journal of Evolutionary Economics 1-26.

Cefis, E., Sabidussi A., Schenk H., 2007, Do mergers of potentially dominant firms foster innovation? An empirical analysis for the manufacturing sector. Utrecht School of Economics, T.C. Koopmans Research Institute, Discussion Paper Series 07-20.

Christensen, C.M., Suarez, F.F., Utterback, J.M., 1998. Strategies for survival in fast-changing industries. Management Science. 44(12, Part 2 of 2), S207-S220.

Cockburn, I.M., Wagner, S., 2010. Patents and the survival of Internet-related IPO. Research Policy. 39(2), 214-228.

Coff, R.W., 1999. How buyers cope with uncertainty when acquiring firms in knowledge-intensive industries: Caveat emptor. Organization Science. 10(2), 144-161.

Cohen, W.M., Klepper, S., 1996. Firm size and the nature of innovation within industries: the case of process and product R\&D. Review of Economics and Statistics. 78(2), 232-243.

Cohen, W.M., Levinthal, D., 1990. Absorptive capacity: a new perspective of learning and innovation. Administrative Science Quarterly. 35, 128-152

Colombo, M.G., Delmastro, M., 2001. Technology use and plant closure. Research Policy. 30(1), 2134.

Doms, M., Dunne, T., Roberts, M.J., 1995. The role of technology use in the survival and growth of manufacturing plants. International Journal of Industrial Organization. 13, 523-542.

Dosi, G., 1988. Sources, procedures and microeconomic effects of innovation. Journal of Economic Literature. 26(3), 1120-1171.

Dunne, T., Roberts, M.J., Samuelson, L., 1988. Patterns of firm entry and exit in the U.S. manufacturing industries. RAND Journal of Economics. 19(4), 495-515.

Dunne, P., Hughes, A., 1994. Age, size, growth and survival: Uk companies in the 1980s. The Journal of Industrial Economics. 42(2), 115-139.

Eisenhardt, K.M., Martin, J.A., 2000. Dynamic capabilities: What are they? Strategic Management Journal. 21(10-11), 1105-1121.

Ericson, R., Pakes, A., 1995. Markov-perfect industry dynamics: A framework for empirical work. Review of Economic Studies. 62(1), 53-82.

Evans, D.S., 1987. The relationship between firm growth, size, and age: Estimates for 100 manufacturing industries. Journal of Industrial Economics. 35(4), 567-581.

Fontana, R., Nesta, L. 2009. Product Innovation and Survival in a High-Tech Industry. Review of Industrial Organization. 34(4) 287-306.

Freeman, J., Carroll, G.R., Hannan, M.T., 1983. The liability of newness: Age dependence in 
organizational death rates. Americal Sociological Review. 48, 692-710.

Gans, J.S., Stern, S., 2003. The product market and the market for 'ideas': commercialization strategies for technology entrepreneurs. Research Policy. 32, 333-350.

Geroski, P.A., Mata, J., Portugal, P. 2010. Founding conditions and the survival of new firms. Strategic Management Journal. 31(5) 510-529.

Gibbs, P.A., 1993. Determinants of corporate restructuring: The relative importance of corporate governance, takeover threat, and free cash flow. Strategic Management Journal. 14, 51-68.

Gort, M., Klepper, S., 1982. Time paths in the diffusion of product innovations. The Economic Journal. 92(367), 630-653.

Graebner, M.E., 2004. Momentum and serendipity: How acquired leaders create value in the integration of technology firms. Strategic Management Journal. 25(8-9), 751-777.

Graebner, M.E, Eisenhardt, K.M., 2004. The seller's side of the story: Acquisition as courtship and governance as syndicate in entrepreneurial firms. Administrative Science Quarterly. 49(3), 366-403.

Granstrand, O., Sjôlander, S., 1990. The acquisition of technology and small firms by large firms. Journal of Economic Behavior \& Organization. 13(3), 367-386.

Grant, R.M., 1996. Prospering in dynamically-competitive environments: Organizational capability as knowledge integration. Organization Science. 7(4), 375-387.

Hall, B.H., 1987. The relationship between firm size and firm growth in the US manufacturing sector. Journal of Industrial Economics. 35(4), 583-606.

Hall, B.H., Mairesse, J., 2006. Empirical studies of innovation in the knowledge-driven economy, Economics of Innovation and New Technologies. 15(4and5), 289-299

Hatch, N.W., Mowery, D.C., 1998. Process innovation and learning by doing in semiconductor manufacturing. Management Science. 44(11), 1461-1477.

Headd, B., 2003. Redefining business success: Distinguishing between closure and failure. Small Business Economics. 21(1), 51-61.

Hitt, M.A., Hoskisson, R.E., Johnson, R.A., Moesel, D.D. 1996. The Market for Corporate Control and Firm Innovation. The Academy of Management Journal. 39(5) 1084-1119.

Hoskisson, R.E., Johnson, R.A., Moesel, D.D., 1994. Corporate divestiture intensity in restructuring firms: Effects of governance, strategy, and performance. Academy of Management Journal. 37(5), 1207-1251.

Hoskisson, R.E., T.A. Turk. 1990. Corporate restructuring: Governance and control limits of the internal capital market. Academy of Management Review. 15(3), 459-477.

Iwai, K., 1984 Schumpeterian Dynamics, Part II. Technological Progress, Firm Growth and “Economic Selection” Journal of Economic Behavior and Organization. 5 (3-4), 321-351.

James, A.D., Georghiou, L., Metcalfe, S.J., 1998. Integrating technology into merger and acquisition decision making. Technovation. 18(8-9), 563-573.

Jenkins, S.P., 1995. Easy estimation methods for discrete-time duration models. Oxford Bulletin of Economics and Statistics. 57(1), 129-138.

Jenkins, S.P., 2004. Survival Analysis. Unpublished manuscript. Institute for Social and Economic Research, University of Essex, Colchester, UK. Downloadable from http://www.iser.essex.ac.uk/teaching/degree/stephenj/ec968/pdfs/ec968lnotesv6.pdf.

Jovanovic, B., 1982. Selection and the evolution of industry. Econometrica. 50(3), 649-670.

Klepper, S., 1996. Entry, exit, growth, and innovation over the product life cycle. American Economic Review. 86(3), 562-583.

Klepper, S., 2002. Firm survival and the evolution of oligopoly. RAND Journal of Economics. 33(1), 37-61. 
Laursen, K., Salter, A., 2006. Open for innovation: The role of openness in explaining innovation performance among U.K. manufacturing firms. Strategic Management Journal. 27(2), 131150.

Lehto, E.L.O., Lehtoranta, M.O., 2004. Becoming an acquirer and becoming acquired. Technological Forecasting and Social Change. 71(6), 635-650.

Leiponen, A., Helfat, C.E., 2010, Innovation objectives, knowledge sources, and the benefits of breadth, Strategic Management Journal, 31(2), 224-236.

Levin, R.C., Klevorick, A.K., Nelson, R.R., Winter, S.G., 1987. Appropriating the returns from industrial research and development. Brooking Papers on Economic Activity. 3, 783-820.

Lockett, A., Thompson, S., 2001. The resource-based view and economics. Journal of Management. 27(6), 723-754.

Mairesse, J., Mohnen, P., 2002. Accounting for innovation and measuring innovativeness: An illustrative framework and an application. American Economic Review Papers and Proceedings. 92(2), 226-230.

Markides, C.C., 1992. The economic characteristics of de-diversifying firms. British Journal of Management. 3(2), 91.

McGuckin, R.H., Nguyen, S.V., 1995. On productivity and plant ownership change: New evidence from the longitudinal research database. RAND Journal of Economics. 26(2), 257-276.

Milgrom, P., Roberts, J., 1995. Complementarities and fit strategy, structure, and organizational change in manufacturing. Journal of Accounting and Economics. 19(2-3), 179-208.

Mitchell, W., 1994. The dynamics of evolving markets: The effects of business sales and age on dissolutions and divestitures. Administrative Science Quarterly. 39(4), 575-602.

Mohnen, P., Roller, L.H., 2005. Complementarities in innovation policy. European Economic Review. 49(6), 1431-1450.

Nelson, R.R., 1991. Why do firms differ, and how does it matter? Strategic Management Journal. 12, 61-74.

Nelson, R.R., Winter, S.G., 1982. An Evolutionary Theory of Economic Change. Belknap Press of Harvard University Press, Cambridge, MA.

OECD-EUROSTAT, 1997. Proposed Guidelines for Collecting and Interpreting Technological Innovation Data, Oslo Manual, $2^{\text {nd }}$ ed. OECD, Paris, France.

Ortega-Argiles, R. Moreno, R., 2007. Firm Competitive Strategies and the Likelihood of Survival. The Spanish Case, Discussion Papers on Entrepreneurship, Growth and Public Policy N.0507. Max Planck Institute of Economics, Jena.

Esteve-Perez, S., Sanchis-Llopis, A., Sanchis-Llopis, J.A., 2004. The determinants of survival of Spanish manufacturing firms. Review of Industrial Organization. 25(3), 251-273.

Pisano, G., 1997. The Development Factory: Unlocking the Potential of Process Innovation. Harvard Business School Press, Boston.

Powell, R.G., 1997. Modelling takeover likelihood. Journal of Business Finance \& Accounting. 24(7\&8), 1009-1030.

Prentice, R.L., Gloeckler, L.A., 1978. Regression analysis of grouped survival data with application to breast cancer data. Biometrics. 34(1), 57-67.

Ranft, A.L., Lord, M.D., 2002. Acquiring new technologies and capabilities: A grounded model of acquisition implementation. Organization Science. 13(4), 420-441.

Reichstein, T., Salter, A., 2006. Investigating the sources of process innovation among UK manufacturing firms. Industrial and Corporate Change. 15(4), 653-682.

Rosenberg, N., 1982. Inside the Black Box. Cambridge University Press, Cambridge, MA.

Sarkar, M., Echambadi, R., Agarwal, R., Sen, B., 2006. The effect of the innovative environment on 
exit of entrepreneurial firms. Strategic Management Journal. 27, 519-539.

Schary, M.A., 1991. The probability of exit. RAND Journal of Economics. 22(3), 339-353.

Schumpeter, J.A., 1934. The Theory of Economic Development. Harvard Economic Studies, Cambridge, Mass.

Teece, D.J., 1986. Profiting from technological innovation: Implications for integration, collaboration, licensing and public policy. Research Policy. 15(6), 285-305.

Teece, D.J., Pisano, G., Shuen, A., 1997. Dynamic capabilities and strategic management. Strategic Management Journal. 18(7), 509-533.

Utterback, J.M., Abernathy, W.J., 1975. A dynamic model of process and product innovation. OMEGA. 3(6), 639-656.

Villalonga, B., McGahan, A.M., 2005. The choice among acquisitions, alliances, and divestitures. Strategic Management Journal. 26, 1183-1208.

Vivarelli, M., Audretsch, D. 1998. The Link between the Entry Decision and Post-entry Performance: Evidence from Italy. ICC. 7(3) 485-500.

Winter, S.G., 1987. Knowledge and competence as strategic assets. D.J. Teece, ed. The Competitive Challenge. Strategies for Industrial Innovation and Renewal. Ballinger Publishing Company, Cambridge, Mass.

Winter, S.G., 1984. Schumpeterian competition in alternative technological regimes. Journal of Economic Behavior \& Organization. 5(3-4), 287-320. 


\begin{tabular}{|c|c|c|c|}
\hline & Chan alioex & $m$ & $\begin{array}{c}\text { Avarige } \\
\text { denmolymen }\end{array}$ \\
\hline \multicolumn{4}{|l|}{$\overline{g a n}$} \\
\hline \multicolumn{4}{|l|}{ Anits } \\
\hline finther & 거.끄로 & $.19 . f_{11}$ & 5.6 \\
\hline MAd & .9 .107 & 9.11 & 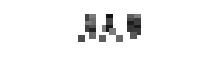 \\
\hline Atitm hrims & $36=$ & $u-$ & 127.: \\
\hline 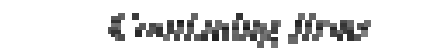 & A.fill & 5.5 & 19.2 \\
\hline thonswings & hI.I7t & & \\
\hline \multicolumn{4}{|l|}{ 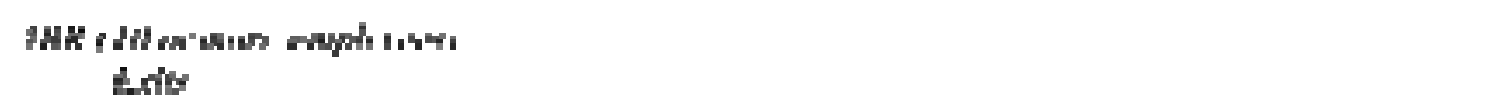 } \\
\hline Futher & ‥러롤 & :s..A & +2 \\
\hline Mat & 1.147 & $9 . x$ & $5:$ \\
\hline mairnving & $2=$ & L.H & Sn+H \\
\hline fimminisy dirws & X..w1 & 70.1 & $7+4$ \\
\hline Chonswions & $1 . .26 \mathrm{~J}$ & & \\
\hline \multicolumn{4}{|l|}{ ins. } \\
\hline \multicolumn{4}{|l|}{ trits } \\
\hline 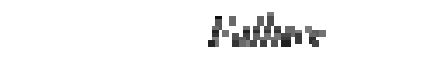 & Nㅔㄴㅣ & II.0 & Ghas \\
\hline Mat & 275 & $k=$ & 1.14: \\
\hline hairming 'm & 72 & $2 \geq$ & {$[4$} \\
\hline rimolentions & 2.97 & 77.5 & 130.0 \\
\hline Ehomplos: & .1 .275 & & \\
\hline
\end{tabular}


Table 2. Frequencies by type of innovation

\begin{tabular}{|c|c|c|c|c|c|c|c|c|c|c|c|c|}
\hline & \multicolumn{3}{|c|}{$\begin{array}{l}\text { Survival } \\
\end{array}$} & \multicolumn{3}{|c|}{ Exit by closure } & \multicolumn{3}{|c|}{ Exit by M\&A } & \multicolumn{3}{|c|}{$\begin{array}{c}\text { Exit by } \\
\text { restructuring }\end{array}$} \\
\hline & $\mathrm{N}$ & $\%$ & Chi2 & $\mathrm{N}$ & $\%$ & $\begin{array}{c}\text { Chi } \\
2\end{array}$ & $\mathrm{~N}$ & $\%$ & Chi2 & $\mathrm{N}$ & $\%$ & Chi2 \\
\hline Product \& process inn. & 1122 & 44.2 & 10.0 & 126 & 32.2 & 20.1 & 121 & 44.0 & 0.2 & 31 & 43.1 & 0.0 \\
\hline Only product inn. & 377 & 14.9 & 0.0 & 52 & 13.3 & 0.8 & 48 & 17.5 & 1.7 & 8 & 11.1 & 0.8 \\
\hline Only process inn. & 154 & 6.1 & 1.5 & 20 & 5.1 & 0.4 & 16 & 5.8 & 0.0 & 0 & 0 & 4.5 \\
\hline Non innovator & 884 & 34.8 & 15.7 & 193 & 49.4 & 30.9 & 90 & 32.7 & 2.0 & 33 & 45.8 & 2.7 \\
\hline Total & 2537 & 100 & & 391 & 100 & & 275 & 100 & & 72 & 100 & \\
\hline Product inn. & 1499 & 59.1 & 10.8 & 178 & 45.5 & 26.3 & 169 & 61.4 & 1.9 & 39 & 54.2 & 0.3 \\
\hline Process inn. & 1276 & 50.3 & 13.7 & 146 & 37.3 & 22.3 & 137 & 49.8 & 0.2 & 31 & 43.1 & 0.9 \\
\hline
\end{tabular}

Note: In each cell the Pearson Chi-square test is calculated on the basis of a 2x2 matrix, which includes the categories complementary to the combination (exit form or survival) x (type of innovative capability), for which the value is reported in the table. Threshold for Chi-square (1) is equal to 2.706 at 10 per cent significance level 
Table 3. Descriptive statistics and Correlation matrix

\begin{tabular}{|c|c|c|c|c|c|c|c|c|c|c|c|c|c|c|c|c|c|}
\hline & Mean & StdDev & (1) & (2) & (3) & (4) & (5) & (6) & (7) & (8) & (9) & (10) & (11) & (12) & (13) & (14) & (15) \\
\hline Survival & 0.77 & 0.418 & 1 & & & & & & & & & & & & & & \\
\hline Exit by closure & 0.12 & 0.324 & $-0.683 *$ & 1 & & & & & & & & & & & & & \\
\hline Exit by $M \& A$ & 0.08 & 0.277 & $-0.561 *$ & $-0.112 *$ & 1 & & & & & & & & & & & & \\
\hline Exit by restructuring & 0.02 & 0.147 & $-0.278 *$ & $-0.055^{*}$ & $-0.045^{*}$ & 1 & & & & & & & & & & & \\
\hline Innovator & 0.63 & 0.482 & $0.069 *$ & $-0.097 *$ & 0.025 & -0.029 & 1 & & & & & & & & & & \\
\hline Product innovator & 0.58 & 0.494 & $0.057^{*}$ & $-0.090 *$ & 0.024 & -0.010 & $0.886^{*}$ & 1 & & & & & & & & & \\
\hline Process innovator & 0.49 & 0.500 & $0.065^{*}$ & $-0.083 *$ & 0.008 & -0.017 & $0.739 *$ & $0.599 *$ & 1 & & & & & & & & \\
\hline Only product inn. & 0.15 & 0.355 & 0.003 & -0.016 & 0.023 & -0.016 & $0.317^{*}$ & $0.358 *$ & $-0.405^{*}$ & 1 & & & & & & & \\
\hline Only process inn. & 0.06 & 0.234 & 0.021 & -0.011 & 0.000 & $-0.037 *$ & $0.189 *$ & $-0.289 *$ & $0.255^{*}$ & $-0.103^{*}$ & 1 & & & & & & \\
\hline Product \& process & 0.43 & 0.495 & $0.055^{*}$ & $-0.078^{*}$ & 0.008 & 0.001 & $0.657^{*}$ & $0.742 *$ & $0.890 *$ & $-0.360 *$ & $-0.214^{*}$ & 1 & & & & & \\
\hline Firm age (months) & 344.8 & 268.2 & $0.070^{*}$ & $-0.059 *$ & -0.015 & $-0.042 *$ & 0.024 & 0.008 & 0.033 & -0.013 & 0.033 & 0.018 & 1 & & & & \\
\hline Firm size & 118.2 & 261.0 & 0.020 & $-0.042 *$ & -0.004 & $0.044 *$ & $0.113^{*}$ & $0.121 *$ & $0.149 *$ & $-0.057^{*}$ & -0.023 & $0.162 *$ & 0.006 & 1 & & & \\
\hline Pavitt1 & 0.20 & 0.403 & 0.002 & 0.029 & -0.030 & -0.014 & $0.131^{*}$ & $0.162^{*}$ & $0.077 *$ & $0.069 *$ & $-0.073 *$ & $0.112 *$ & $-0.094 *$ & $0.062 *$ & 1 & & \\
\hline Pavitt2 & 0.33 & 0.471 & -0.019 & -0.021 & $0.055 *$ & -0.004 & $-0.043^{*}$ & $-0.048^{*}$ & 0.003 & $-0.063 *$ & 0.013 & -0.003 & -0.002 & $0.039 *$ & $-0.357^{*}$ & 1 & \\
\hline Pavitt3 & 0.12 & 0.323 & $0.052^{*}$ & -0.024 & $-0.053 *$ & 0.003 & $0.100^{*}$ & $0.134 *$ & $-0.047^{*}$ & $0.202 *$ & $-0.079 *$ & -0.010 & 0.020 & -0.026 & $-0.185^{*}$ & $-0.259 *$ & 1 \\
\hline Pavitt4 & 0.35 & 0.476 & -0.019 & 0.012 & 0.007 & 0.014 & $-0.135^{*}$ & $-0.181^{*}$ & $-0.036^{*}$ & $-0.133^{*}$ & $0.103 *$ & $-0.085^{*}$ & $0.068 *$ & $-0.073 *$ & $-0.367 *$ & $-0.513^{*}$ & $-0.266^{*}$ \\
\hline
\end{tabular}

Note: * significant at 10 percent level 
Table 4. Competing risks model - Estimates of multinomial logistic regression

\begin{tabular}{|c|c|c|c|c|c|c|c|}
\hline \multirow[b]{2}{*}{ Exit mode } & \multirow[b]{2}{*}{ Variables } & \multicolumn{2}{|c|}{ Model (1) } & \multicolumn{2}{|c|}{ Model (2) } & \multicolumn{2}{|c|}{ Model (3) } \\
\hline & & Coeff & SE & Coeff & SE & Coeff. & $\mathrm{SE}$ \\
\hline \multirow[t]{15}{*}{ Failure } & innovator & 0.62 & $(0.106)^{* * *}$ & & & & \\
\hline & product inn. & & & 0.75 & $(0.134)^{* *}$ & & \\
\hline & process inn. & & & 0.78 & $(0.134) *$ & & \\
\hline & only product inn. & & & & & 0.69 & $(0.163)^{* *}$ \\
\hline & only process inn. & & & & & 0.65 & $(0.237)^{*}$ \\
\hline & product \& process & & & & & 0.59 & $(0.120)^{* * *}$ \\
\hline & Ln(age) & 0.38 & $(0.328)^{* * *}$ & 0.38 & $(0.327)^{* * *}$ & 0.38 & $(0.328)^{* * *}$ \\
\hline & Ln(size) & 0.29 & $(0.274)^{* * *}$ & 0.28 & $(0.273)^{* * *}$ & 0.29 & $(0.274)^{* * *}$ \\
\hline & age $*$ size & 1.09 & $(0.041)^{* *}$ & 1.09 & $(0.041)^{* *}$ & 1.09 & $(0.041)^{* *}$ \\
\hline & $(\text { age })^{\wedge} 2$ & 1.04 & $(0.029)$ & 1.04 & $(0.029)$ & 1.04 & $(0.029)$ \\
\hline & $(\text { size })^{\wedge 2}$ & 1.07 & $(0.023)^{* * *}$ & 1.07 & $(0.023)^{* * *}$ & 1.07 & $(0.023)^{* * *}$ \\
\hline & Pavitt1 & 1.23 & $(0.138)$ & 1.23 & $(0.139)$ & 1.23 & $(0.139)$ \\
\hline & Pavitt2 & 0.96 & $(0.125)$ & 0.96 & $(0.125)$ & 0.96 & $(0.125)$ \\
\hline & Pavitt3 & 0.92 & $(0.185)$ & 0.89 & $(0.189)$ & 0.90 & $(0.189)$ \\
\hline & Ln(time) & 1.85 & $(0.079)^{* * *}$ & 1.85 & $(0.079) * * *$ & 1.85 & $(0.079)^{* * *}$ \\
\hline \multirow[t]{15}{*}{$M \& A$} & innovator & 1.28 & $(0.134)^{*}$ & & & & \\
\hline & product inn. & & & 1.48 & $(0.160)^{* *}$ & & \\
\hline & process inn. & & & 0.82 & $(0.153)$ & & \\
\hline & only product inn. & & & & & 1.62 & $(0.185)^{* * *}$ \\
\hline & only process inn. & & & & & 1.01 & $(0.273)$ \\
\hline & product \& process & & & & & 1.22 & $(0.145)$ \\
\hline & Ln(age) & 0.40 & $(0.376)^{* *}$ & 0.38 & $(0.378)^{* *}$ & 0.39 & $(0.377)^{* *}$ \\
\hline & Ln(size) & 0.55 & $(0.361)^{*}$ & 0.54 & $(0.365)^{*}$ & 0.53 & $(0.364)^{*}$ \\
\hline & age * size & 1.02 & $(0.045)$ & 1.02 & $(0.045)$ & 1.02 & $(0.045)$ \\
\hline & $(\text { age })^{\wedge} 2$ & 1.08 & $(0.029) * *$ & 1.08 & $(0.029) * * *$ & 1.08 & $(0.029)^{* * *}$ \\
\hline & $(\text { size })^{\wedge 2}$ & 1.05 & $(0.029)$ & 1.05 & $(0.029) *$ & 1.05 & $(0.029) *$ \\
\hline & Pavitt1 & 0.74 & $(0.183)$ & 0.71 & $(0.185)^{*}$ & 0.71 & $(0.185)^{*}$ \\
\hline & Pavitt2 & 1.24 & $(0.139)$ & 1.21 & $(0.139)$ & 1.22 & $(0.139)$ \\
\hline & Pavitt3 & 0.48 & $(0.265)^{* * *}$ & 0.44 & $(0.269)^{* * *}$ & 0.44 & $(0.269)^{* * *}$ \\
\hline & Ln(time) & 1.78 & $(0.093)^{* * *}$ & 1.78 & $(0.093) * * *$ & 1.78 & $(0.093)^{* * *}$ \\
\hline \multirow[t]{15}{*}{ Restructuring } & innovator & 0.46 & $(0.248)^{* * *}$ & & & & \\
\hline & product inn. & & & 0.86 & $(0.304)$ & & \\
\hline & process inn. & & & 0.60 & $(0.300)^{*}$ & & \\
\hline & only product inn. & & & & & 0.49 & $(0.408)^{*}$ \\
\hline & only process inn. & & & & & 0.00 & + \\
\hline & product \& process & & & & & 0.52 & $(0.264)^{* *}$ \\
\hline & Ln(age) & 0.77 & $(0.774)$ & 0.76 & $(0.769)$ & 0.73 & $(0.779)$ \\
\hline & Ln(size) & 5.83 & $(0.922)^{*}$ & 5.21 & $(0.921)^{*}$ & 6.00 & $(0.923)^{*}$ \\
\hline & age * size & 1.02 & $(0.095)$ & 1.02 & (0.095) & 1.02 & $(0.094)$ \\
\hline & $(\text { age })^{\wedge} 2$ & 0.97 & $(0.056)$ & 0.97 & $(0.056)$ & 0.98 & $(0.056)$ \\
\hline & $(\text { size })^{\wedge} 2$ & 0.87 & $(0.072)^{*}$ & 0.88 & $(0.072)^{*}$ & 0.87 & $(0.072)^{* *}$ \\
\hline & Pavitt1 & 0.68 & $(0.352)$ & 0.63 & $(0.355)$ & 0.63 & $(0.353)$ \\
\hline & Pavitt2 & 0.79 & $(0.283)$ & 0.78 & $(0.284)$ & 0.77 & $(0.284)$ \\
\hline & Pavitt3 & 0.90 & (0.388) & 0.78 & (0.399) & 0.82 & $(0.394)$ \\
\hline & Ln(time) & 3.19 & $(0.245)^{* * *}$ & 3.18 & $(0.245)^{* * *}$ & 3.20 & $(0.245)^{* * *}$ \\
\hline Log-likelihood & & 5551.17 & & -5551.43 & & -5545.21 & \\
\hline LR Chi Square & & 340.1 & & 339.6 & & 352.1 & \\
\hline
\end{tabular}

Notes: Base category is the continuing state (or survival). Coefficients are reported in the form of odds ratios. Standard errors in parentheses. $* * * 1 \%, * * 5 \%$, * 1\% significant. Observations $=249287$

${ }^{+}$This result is due to the absence of observations in this particular category: firms that experience a radical restructuring and have developed only process innovations (see also Table 5). 
Table 5. Competing risks model - Estimates of complementary log-log regression

\begin{tabular}{|c|c|c|c|c|c|c|c|c|c|}
\hline \multirow[b]{2}{*}{ Variables } & \multicolumn{3}{|c|}{ Failure } & \multicolumn{3}{|c|}{$M \& A$} & \multicolumn{3}{|c|}{ Restructuring } \\
\hline & Model (1) & Model (2) & Model (3) & Model (1) & Model (2) & Model (3) & Model (1) & Model (2) & Model (3) \\
\hline \multirow[t]{2}{*}{ innovator } & 0.62 & & & 1.28 & & & 0.46 & & \\
\hline & $(0.106)^{* * *}$ & & & $(0.134)^{*}$ & & & $(0.248)^{* * *}$ & & \\
\hline \multirow[t]{2}{*}{ product inn. } & & 0.75 & & & 1.48 & & & 0.86 & \\
\hline & & $(0.133)^{* *}$ & & & $(0.160)^{* *}$ & & & $(0.304)$ & \\
\hline \multirow[t]{2}{*}{ process inn. } & & 0.78 & & & 0.82 & & & 0.60 & \\
\hline & & $(0.134)^{*}$ & & & $(0.153)$ & & & $(0.299)^{*}$ & \\
\hline \multirow[t]{2}{*}{ only product inn. } & & & 0.69 & & & 1.62 & & & 0.49 \\
\hline & & & $(0.163)^{* *}$ & & & $(0.185)^{* * *}$ & & & $(0.408)^{*}$ \\
\hline \multirow{2}{*}{ only process inn. } & & & 0.66 & & & 1.01 & & & + \\
\hline & & & $(0.236)^{*}$ & & & $(0.273)$ & & & + \\
\hline \multirow[t]{2}{*}{ product \& process } & & & 0.59 & & & 1.22 & & & 0.52 \\
\hline & & & $(0.120)^{* * *}$ & & & $(0.145)$ & & & $(0.264)^{* *}$ \\
\hline \multirow[t]{2}{*}{ Ln(age) } & 0.38 & 0.39 & 0.38 & 0.4 & 0.39 & 0.39 & 0.77 & 0.76 & 0.73 \\
\hline & $(0.327)^{* * *}$ & $(0.326)^{* * *}$ & $(0.327)^{* * *}$ & $(0.375)^{* *}$ & $(0.377)^{* *}$ & $(0.377)^{* *}$ & $(0.774)$ & $(0.768)$ & $(0.778)$ \\
\hline \multirow{2}{*}{ Ln(size) } & 0.29 & 0.29 & 0.29 & 0.55 & 0.54 & 0.54 & 5.86 & 5.23 & 6.03 \\
\hline & $(0.273)^{* * *}$ & $(0.272) * * *$ & $(0.273)^{* * *}$ & $(0.361)^{*}$ & $(0.364)^{*}$ & $(0.363)^{*}$ & $(0.922)^{*}$ & $(0.920)^{*}$ & $(0.922)^{*}$ \\
\hline \multirow{2}{*}{ age * size } & 1.09 & 1.09 & 1.09 & 1.02 & 1.02 & 1.02 & 1.02 & 1.02 & 1.02 \\
\hline & $(0.041)^{* *}$ & $(0.041)^{* *}$ & $(0.041)^{* *}$ & $(0.045)$ & $(0.045)$ & $(0.045)$ & $(0.095)$ & $(0.095)$ & $(0.094)$ \\
\hline \multirow[t]{2}{*}{$(\text { age })^{\wedge} 2$} & 1.04 & 1.04 & 1.04 & 1.08 & 1.08 & 1.08 & 0.97 & 0.97 & 0.98 \\
\hline & $(0.029)$ & $(0.029)$ & $(0.029)$ & $(0.029)^{* *}$ & $(0.029) * * *$ & $(0.029)^{* *}$ & $(0.056)$ & $(0.056)$ & $(0.056)$ \\
\hline \multirow[t]{2}{*}{$(\text { size })^{\wedge} 2$} & 1.07 & 1.07 & 1.07 & 1.05 & 1.05 & 1.05 & 0.87 & 0.88 & 0.87 \\
\hline & $(0.023)^{* * *}$ & $(0.023) * * *$ & $(0.023)^{* * *}$ & $(0.029)$ & $(0.029)^{*}$ & $(0.029)^{*}$ & $(0.072)^{*}$ & $(0.071)^{*}$ & $(0.072)^{* *}$ \\
\hline \multirow[t]{2}{*}{ Pavitt1 } & 1.23 & 1.24 & 1.23 & 0.74 & 0.71 & 0.71 & 0.68 & 0.63 & 0.63 \\
\hline & $(0.137)$ & $(0.139)$ & $(0.139)$ & $(0.183)$ & $(0.185)^{*}$ & $(0.185)^{*}$ & $(0.352)$ & $(0.355)$ & $(0.353)$ \\
\hline \multirow[t]{2}{*}{ Pavitt2 } & 0.96 & 0.96 & 0.96 & 1.24 & 1.21 & 1.22 & 0.79 & 0.78 & 0.77 \\
\hline & $(0.125)$ & $(0.125)$ & $(0.125)$ & $(0.139)$ & (0.139) & (0.139) & $(0.283)$ & $(0.284)$ & $(0.283)$ \\
\hline \multirow[t]{2}{*}{ Pavitt3 } & 0.92 & 0.89 & 0.9 & 0.48 & 0.44 & 0.44 & 0.9 & 0.78 & 0.82 \\
\hline & $(0.185)$ & $(0.189)$ & $(0.189)$ & $(0.265)^{* * *}$ & $(0.269) * * *$ & $(0.269) * * *$ & $(0.388)$ & $(0.399)$ & $(0.394)$ \\
\hline \multirow{2}{*}{ Ln(time) } & 1.85 & 1.85 & 1.85 & 1.78 & 1.78 & 1.78 & 3.19 & 3.18 & 3.19 \\
\hline & $(0.079)^{* * *}$ & $(0.079) * * *$ & $(0.079)^{* * *}$ & $(0.093)^{* * *}$ & $(0.093)^{* * *}$ & $(0.093)^{* * *}$ & $(0.245)^{* * *}$ & $(0.245)^{* * *}$ & $(0.245)^{* * *}$ \\
\hline Log-likelihood & -2831.4 & -2831.3 & -2830.9 & -2104.8 & -2103.5 & -2103.1 & -615.8 & -617.4 & -612.0 \\
\hline LR Chi Square & $168.6^{* * *}$ & $168.7 * * *$ & $169.5^{* * *}$ & $85.3^{* * *}$ & $88.0 * * *$ & $88.8 * * *$ & $86.0 * * *$ & $82.7 * * *$ & $84.9 * * *$ \\
\hline
\end{tabular}

Number of observations $=249287$. Coefficients are reported in the form of odds ratios. Standard errors in parenthesis. *** $1 \%$, ** $5 \%$, * $10 \%$ significant.

'+ Observations were dropped because the value of onlypcs equal to 1 predicts failure perfectly. 
Table 6. Test of frailty

\begin{tabular}{|c|c|c|c|c|}
\hline rho & Coeff. & Std. Err. & $\begin{array}{l}\text { Likelihood } \\
\text { chibar2 }\end{array}$ & $\begin{array}{l}\text { test of rho }=0 \\
\text { Prob }>= \\
\text { chibar2 }\end{array}$ \\
\hline \multicolumn{5}{|l|}{ Logistic model } \\
\hline \multicolumn{5}{|l|}{ Model (1) } \\
\hline Exit by closure & 0.0729 & 0.0346 & 0.70 & 0.201 \\
\hline Exit by M\&A & 0.0738 & 0.0329 & 0.75 & 0.193 \\
\hline Exit by restructuring & 0.0185 & 0.0291 & 0.04 & 0.418 \\
\hline \multicolumn{5}{|l|}{ Model (2) } \\
\hline Exit by closure & 0.0725 & 0.0354 & 0.67 & 0.207 \\
\hline Exit by M\&A & 0.0738 & 0.0330 & 0.74 & 0.195 \\
\hline Exit by restructuring & 0.0189 & 0.0340 & 0.03 & 0.430 \\
\hline \multicolumn{5}{|l|}{ Model (3) } \\
\hline Exit by closure & 0.0729 & 0.0347 & 0.70 & 0.201 \\
\hline Exit by M\&A & 0.0737 & 0.0332 & 0.73 & 0.196 \\
\hline Exit by restructuring & 0.0185 & 0.0288 & 0.04 & 0.417 \\
\hline \multicolumn{5}{|c|}{ Complementary log-log model } \\
\hline \multicolumn{5}{|l|}{ Model (1) } \\
\hline Exit by closure & 0.1360 & 0.0602 & 0.70 & 0.201 \\
\hline Exit by M\&A & 0.1375 & 0.0570 & 0.75 & 0.194 \\
\hline Exit by restructuring & 0.0364 & 0.0560 & 0.04 & 0.418 \\
\hline \multicolumn{5}{|l|}{ Model (2) } \\
\hline Exit by closure & 0.1352 & 0.0616 & 0.67 & 0.207 \\
\hline Exit by M\&A & 0.1374 & 0.0572 & 0.74 & 0.195 \\
\hline Exit by restructuring & 0.0370 & 0.0654 & 0.03 & 0.430 \\
\hline \multicolumn{5}{|l|}{ Model (3) } \\
\hline Exit by closure & 0.1359 & 0.0603 & 0.70 & 0.201 \\
\hline Exit by M\&A & 0.1372 & 0.0576 & 0.73 & 0.197 \\
\hline Exit by restructuring & 0.0364 & 0.0555 & 0.04 & 0.417 \\
\hline
\end{tabular}

